\title{
Arts of Inclusion, or, How to Love a Mushroom
}

\author{
Anna Tsing, for the Matsutake Worlds Research Group
}

Next time you walk through a forest, look down. A city lies under your feet. If you were somehow to descend into the earth, you would find yourself surrounded by the city's architecture of webs and filaments. Fungi make those webs as they interact with the roots of trees, forming joint structures of fungus and root called 'mycorrhiza'. Mycorrhizal webs connect not just root and fungus, but, by way of fungal filaments, tree and tree, connecting up the forest in entanglements. This city is a lively scene of action and interaction. There are many ways to eat here and to share food. There is recognizable hunting in the city: for example, some fungi lasso little soil worms called nematodes for dinner. But this is just the crudest way to attune one's digestion. Mycorrhizal fungi siphon energy-giving sugars from trees for their use. Some of those sugars are re-distributed through the fungal network from tree to tree. Others support dependent plants, such as mushroom-loving 'mycophiles' that tap the network to send out pale or colourful stems of flowers (e.g., Indian pipes, coral-root orchids). Meanwhile, like an inside-out stomach, fungi secrete enzymes into the soil around them, digesting organic material and even rocks, and absorbing nutrients released in the process. These nutrients are also available then for the trees and other plants, which use them to produce more sugar for themselves and the network. In this process, too, there is a whole lot of smelling going on, as plants and animals and fungi sniff out not just good meals but also good partners. And what wonderful smells, even for an animal nose, like mine. (Some fungi, such as truffles, depend on animals to smell out their reproductive bodies, to spread around their spores.) Reach down and smell a clot of forest earth: it smells like the underground city of fungi. ${ }^{1}$

Like human cities, this underground city is a site of cosmopolitan transactions. Unfortunately, humans have mainly ignored this lively cosmopolitanism. We have built our cities through destruction and simplification, chopping down forests to replace them with food-growing plantations and living on asphalt

\footnotetext{
1 This essay draws from collaborative research conducted by the Matsutake Worlds Research Group: Timothy Choy, Michael Hathaway, Miyako Inoue, Lieba Faier, Shiho Satsuka, and myself. Preliminary research in Oregon was supported by a University of California Pacific Rim grant. Research in Japan was supported by a grant from the Toyota Foundation. At the invitation of the editors of this special issue, this essay was also published in the journal Manoa 2(22), 2010. I am grateful to Thom van Dooren and Deborah Bird Rose for inspiring this essay. My deepest thanks go to Andy Moore, Dr. Fumihiko Yoshimura, Dr. Henning Knudsen, and many others whom I do not mention by name in this essay for allowing me to think through their work.
} 
and concrete. In agribusiness plantations, we coerce plants to grow without the assistance of other beings, including fungi in the soil. We replace fungally supplied nutrients with fertilizers gained from mining and chemical plants, with their trails of pollution and exploitation. We breed our crops for isolation in chemical stews, crippling them just as much as caged and beakless chickens. We maim and simplify crop plants until they no longer know how to participate in multispecies worlds. One of the many extinctions our development projects aim to produce is the cosmopolitanism of the underground city. And almost no one notices, because so few humans even know of the existence of that city.

Yet a good many of those few who do notice fungi love them with a breathless passion. Gourmets, herbalists, and those who would remediate world ecology often become devotees of the fungal world. Wild mushroom foragers praise their unexpected bounty, their colours, tastes, and smells, and their promise of a livelihood in the woods. How many times have foragers told me of dodging other obligations, having succumbed to 'mushroom fever', the wild thrill of the chase? Even commercial agents are giddy with the unpredictability of their untameable commodity. Scientists who study fungi rave about their secrets in a manner quite dissimilar to scholars of fruit flies or HeLa cells. And, while some fungal devotees are content with private association, others long to share their passion with the world.

How do lovers of fungi practice arts of inclusion that call to others? In these times of extinction, when even slight acquaintance can make the difference between preservation and callous disregard, we might want to know.

\section{Noticing}

Henning Knudsen, curator of fungi at the Copenhagen University's Botanical Museum, shows me around the fungi collection at the herbarium in April 2008. At first the aisles seem neat and anonymous. Then we pull out the folded sheets to expose dried specimens, each named and labelled by its collector. Hiding in their dust lie the shrivelled but still talking mushrooms, bringing their names and the names of their collectors into the great story of life on earth.

Taxonomy is not very popular these days; indeed, detractors think of it as spoiling enjoyment through dry classification. But, handling the specimens at the herbarium, it is easy to imagine the pleasure of naming. Here, through naming, we notice the diversity of life. Collecting went together with painting, again an art of noticing. 


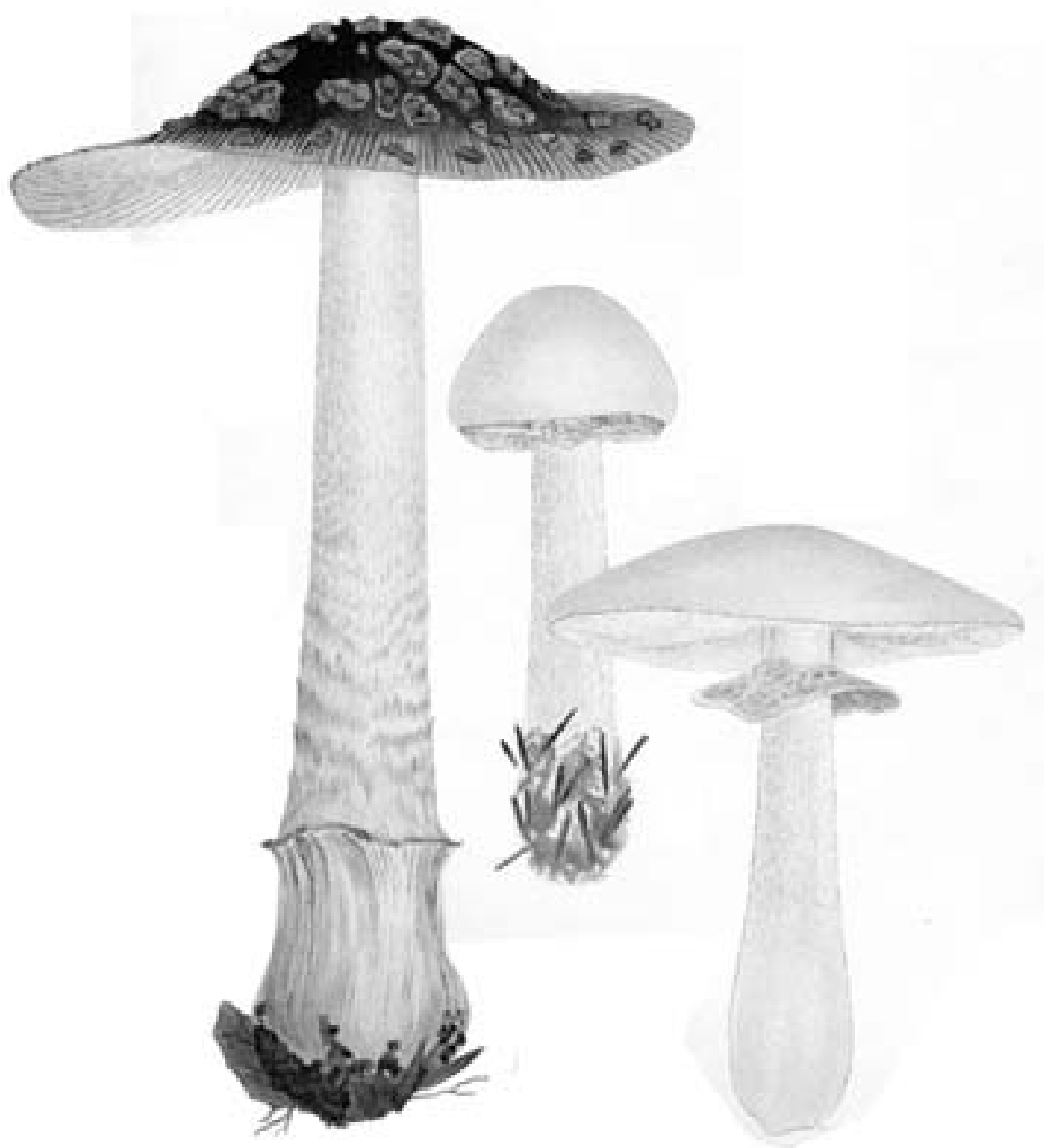

Northern Europe, including Britain, is the homeland of popular botanizing, the collecting and naming of plants. Still, noticing fungi did not come easily, Dr. Knudsen explains, because northern Europeans have despised mushroomsperhaps a reminder of their pagan past. It took a nineteenth-century Frenchborn king in Sweden, Karl Johan, to bring even the prize king bolete (cep, porcini) to the attention of Scandinavians, and the mushroom is still known by his name. Besides, fungi are difficult to collect and identify, because their bodies tend to be underground. Only their reproductive organs, the mushrooms, come up into the air, and those only sporadically-sometimes across intervals of many years. 
Dr. Knudsen tells me about Elias Fries (1794-1878), the father of modern systematic mycology. Like Linnaeus, Fries was a Swede and a lover of plants; Fries extended Linnaean botany to the world of fungi. His work was made possible through a combination of extraordinary memory and extraordinary passion. He recognized 5000 species, remembering them from year to year across the mushroom-empty times. Many of the specimens were collected from near the village in which he was born, where he first learned to love mushrooms. Dr. Knudsen remembers him writing about this early, persistent love. When, as a boy, he found an enormous specimen of the species Tricholoma collosum, he was thrilled: 'I love my sister, I love my father, but this is better', Dr. Knudsen recalls as the sense of his writing. Dr. Knudsen gives me a copy of Fries' memoir, which has been translated from Latin into English. I can't find the passage Dr. Knudsen recalls, but equally passionate love stories jump from the page:

To this day, more than half a century later, I remember with gratitude the admiration that seized me when in 1806 I went with my mother to a burnt-down forest to pick strawberries and there I succeeded in finding an unusually large specimen of Hydnum coralloides, which was the first thing that induced me to study fungi. (140-141)

Afterwards, he noticed fungi everywhere, and, indeed, devoted his life to noticing them. Through his arts of description, Fries brought fungi to public attention. His enthusiasm founded a genealogy of systematic mycologists, to which Dr. Knudsen, mushroom sociologist and coeditor of Nordic Macromycetes, is one heir. ${ }^{2}$

This is a genealogy that has recruited members from far beyond northern Europe. To appreciate the wide-reaching pleasures of taxonomy, one need only call up the quirky naturalist Minakata Kumagusu (1867-1941), remembered for offering the Emperor of Japan a box of horse manure - with interesting specimens of slime mould. ${ }^{3}$ Minakata's watercolours bring together art and collection, drawing us into attentive appreciation. The colours swirl; the fungi pose: the herbarium is alive.

2 L. Hansen \& H. Knudsen are coeditors of the three-volume funga, Nordic Macromycetes.

3 Alan Christy, personal communication 2008. See Blacker (2000). 


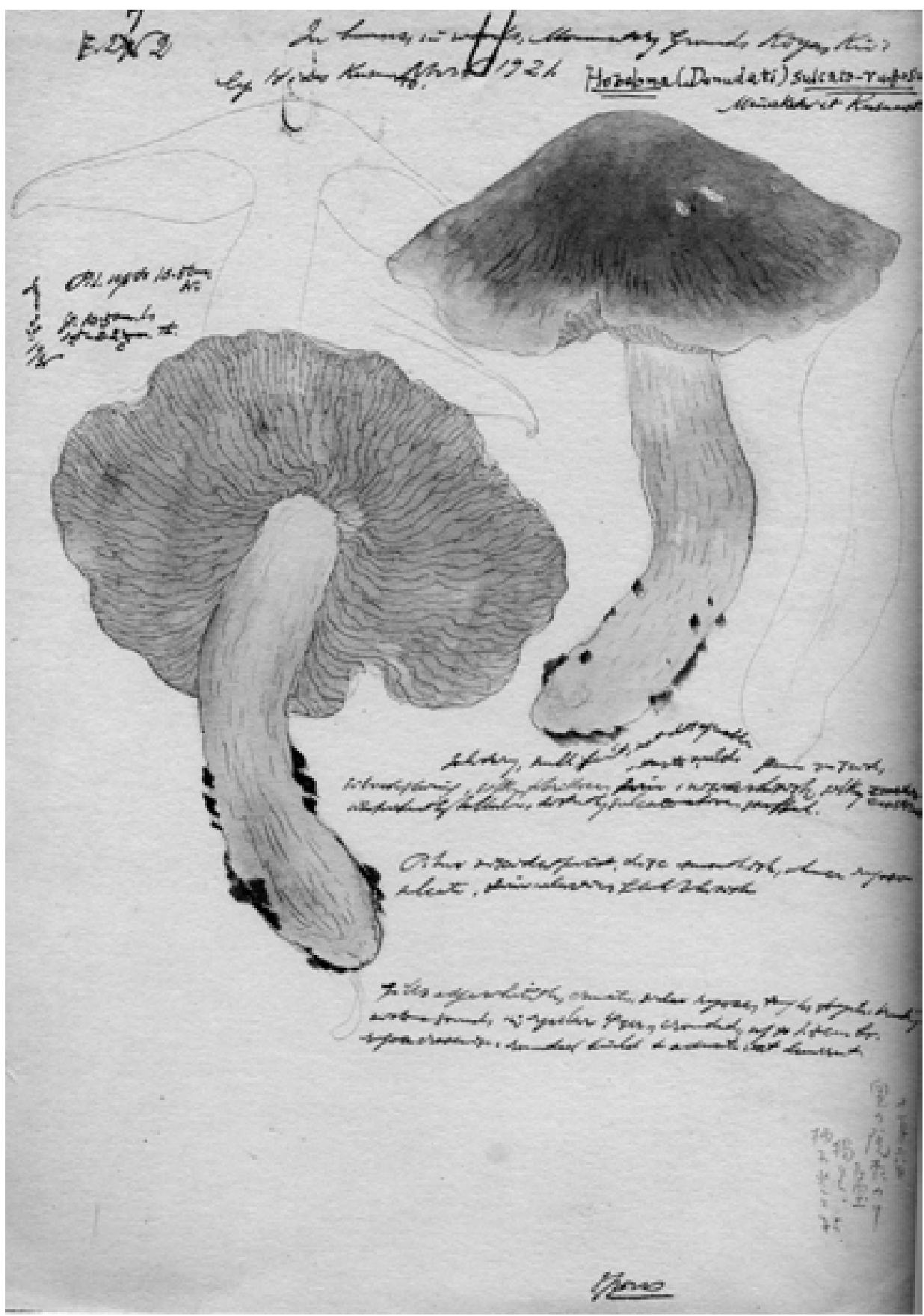


Noticing inspires artists as well as naturalists. American composer John Cage (1912-1992) was a mushroom hunter who thought noticing mushrooms and noticing sounds in music were related skills. In contrast to other musicians, he wanted a music that forced listeners to attend to all the sounds around them, whether composed or incidental; noticing mushrooms was a way of teaching this open yet focused attention. In one of his compositions, one-minute anecdotes are performed in random order to draw listeners to attend to indeterminacy (also the name of the piece). Many of the stories are about people's interactions with mushrooms. Mushrooms are unpredictable; they help one listen. In this entry (\#113), Cage is explicit: ${ }^{4}$

Music and mushrooms:

two words next to one

another in many dictionaries.

Where did he

write The Three-Penny Opera?

Now he's

buried below the grass at the

foot of High Tor.

Once the season changes

from summer to fall,

given sufficient rain,

or just the

mysterious dampness that's in the

earth, mushrooms

grow there,

carrying on,

am sure,

I

business of working with

sounds.

That we

have no ears to hear the

music the spores shot off

from basidia make obliges us

to busy ourselves microphonically.

Basidia are part of mushroom reproductive organs; from basidia, spores are 'shot off' into the air. One mushroom, the 'cannonball fungus' (Sphaerobolus

4 Spacing in the original. Mushroom-related sections of Indeterminacy can be found at <http://www. mundusloci.org/fungus/culture/cage2.htm $>$ (accessed Aug. 2010). See also <http://www.lcdf.org/ indeterminacy/index.cgi $>$ by Eddie Kohler (accessed Aug. 2010). Since the stories are gathered from various Cage books and performances, put back together in new performances, they thwart the determinacy of standard citation practices. 
stellatus), throws out its spore mass with a sometimes-audible pop (but not from basidia). For most mushrooms, however, the shooting-off of spores cannot be heard by human ears. In the sounds we miss, Cage wants us to find inspiration for music.

The parsed, anecdotal style of Indeterminacy is reminiscent of other formal poetics, such as haiku. Noticing mushrooms-especially those aromatic delights Japanese call matsutake - has not escaped haiku poets as a subject. Indeterminacy similarly guides the haiku artist's hand, as in this poem by Kyorai Mukai (1651-1704). ${ }^{5}$

Matsutake yo hito

Ni toraruru hana no saki

Matsutake;

Taken by someone else

Right in front of my nose.

Matsutake (Tricholoma matsutake and allies) are much-loved mushrooms in Japan. They cannot be cultivated, so they bring mushroom lovers out to search in pine forests. They are difficult to spot, and, for the mushroom hunter, the idea that someone else might take the mushroom that is the object of one's own desire is frustrating. We must look more carefully.

Phrasing and sound draw us into a world where we can notice fungi. Even a single valued species group, such as matsutake, can inspire rich cosmopolitan worlds of mushroom loving. Perhaps Kyorai's poem can spur us to consider those arts of inclusion involving just this one mushroom.

\section{Conjuring matsutake worlds: toward a democratic science}

Under the name Matsiman (Americans sometimes call matsutake matsi), Andy Moore has dedicated his life to producing and spreading knowledge about matsutake mushrooms. Moore is not a commercial producer; matsutake cannot be cultivated. He is not a gourmet cook; he doesn't even like the taste and smell of matsutake. He is not a trained scientist, although he participates in matsutake-oriented science. Instead, his goal is to make knowledge accessible. He wants a democratic, inclusive science. Matsutake is the object with which

5 Translated and published by Reginald Blyth. 
he spreads knowledge - and his vision of democratic science. On his web page, matsiman.com, Moore posts everything he can find about matsutake and opens discussion about it. ${ }^{6}$

Matsutake are mycorrhizal inhabitants of northern hemisphere forests, associating particularly with conifers such as pine. It's a wide-ranging species group, with populations stretching across Eurasia, down through North Africa, and across the Atlantic into Canada, the United States and Mexico. In most of the places where the mushrooms grow, they are not much appreciated. Europeans first called them Tricholoma nauseosum to indicate their dislike of the smell. (U.S. mushroomer David Aurora describes it as 'a provocative compromise between "red hots" and dirty socks' (191).) But for Japanese the smell is 'translucent'. Grilled or cooked in soup, matsutake are an expensive gourmet treat as well as a sign of the beauty of the autumn season.

Until the 1970s, Japanese pine forests were a rich source of matsutake. But pine forests, associated with village life, declined after World War II. In this same period, Japanese incomes rose. In the 1980s, Japan began importing matsutake from around the world. Prices were high; mushroom entrepreneurs rushed to enter the fray. At first, Japanese in diaspora, who had found mushrooms for their own use abroad, guided importers. But soon enough, all kinds of people were picking matsutake - whether or not they liked the mushroom for their own use.

Andy Moore was one of these people. Originally from Louisiana, he found his way into the Oregon woods during the U.S. war in Vietnam. Enlisted as a soldier, he was disillusioned by what he saw and experienced there. He felt lucky when he managed to aggravate a childhood injury; he was sent home. For some time, he drove a jeep at a U.S. marine base, but one day he received word that he was to be sent back to Southeast Asia. He was not willing to go. With pride, he recounts how he returned the jeep and walked out of the gates AWOL. Unwilling to be captured, he ran to the forest. He made a living in various kinds of forest work, such as cutting firewood. He loved the forest. It gave him a new goal: 'To live in the woods and never pay rent'.

At the very end of the 1980s, matsutake madness came to the U.S. Pacific Northwest. The woods filled with pickers. Matsutake buyers set up tents by the side of the road to begin the mushrooms' journey to Japan. Japan was still flush from the boom economy, and prices were very good; pickers hoped to strike it rich with 'white gold'. Moore tried picking and found it very much to his liking.

$6<$ http://www.matsiman.com/> (accessed Aug. 2010). 
Moore had an ideal situation for picking - and studying - the mushrooms. He had obtained a position as the caretaker for a large private forest. He lived in a small cabin at the top of the property; his job allowed him plenty of time and opportunity to explore it. The matsutake on his property were just sitting there waiting to be picked. Because matsutake have a long-term relationship with particular trees, the best way to pick is to go to the same trees every year to see if there are mushrooms. But most pickers in the U.S. Pacific Northwest pick on national forests with open access; they go back to the same trees, but, often enough, other pickers have beat them to the harvest. ('Matsutake; taken by someone else right in front of my nose!') Moore's situation was unique: he had a large forest area to harvest, and a locked gate to keep out other harvesters.

The exclusive situation woke his curiosity about the mushrooms. When the fungus is not fruiting, the area around even the most heavily mycorrhizal trees is empty and unpromising; suddenly and unexpectedly mushrooms spring up. What factors control when mushrooms appear? Moore knew various contradictory rumours about this question, but there seemed to be no solid, experimental knowledge. So he decided to start his own experiment. Because other pickers did not intrude on his haven, he was able to mark all the spots where matsutake appeared. Then it was possible to keep records of exactly when they appeared, how many, what weight. These records could be correlated with rainfall, temperature, price, and other factors.

Moore did not have either training or mentoring for his experiments. He just started doing them. Later, he worked with U.S. Forest Service researchers on their projects and became a co-author on several papers, but there he was an assistant without the ability to frame questions or suggest methods. On his own, he was forced to invent science by his own means. Obscure terminology, standardized scales, and sophisticated testing procedures hardly seemed necessary to him. Instead, he started with the questions pickers want to know: when and where do the mushrooms appear?

With some startling results in hand (his mushrooms responded to temperature not rainfall), Moore decided to make his results public. In 1998, Moore opened the Matsiman.com website. The site would not, however, be Moore's personal blog; instead, he would facilitate the making and exchange of knowledge. Everyone, the site suggests, can do research; all it takes is curiosity. 'Who is Matsiman?' the site poses.

Anyone who loves hunting, learning, understanding, protecting, educating others, and respects matsutake mushroom and its habitat is matsiman. Those of us who can't get enough understanding, constantly trying to determine what caused this or that to happen, or not happen. 
We are not limited to nationality, gender, education, or age group. Anyone can be a matsiman. There is at least one in every picking community. $^{7}$

To appreciate the extraordinary nature of this public knowledge, it is important to allow Moore his self-appointed eccentricity. His forest caretaker position has ended; but he has found a job as a campground host, allowing him to live yearround in a motor home as a steward of public lands. To live in the woods and never pay rent! Meanwhile, he is devoted to stray cats, smoking, and trying mushroom experiments. He tries out various mushroom-based commodities, such as smoked mushroom seasoning and dried mushroom snacks. It seems unlikely that such experiments generate much of an income, but they keep Moore's exuberance for mushrooms high. Meanwhile, there is nothing proprietary about any of the many ideas he generates. He believes that all knowledge should be accessible; the Matsiman site builds a community of knowledge. Moore loves nothing better than to introduce new people to the world of matsutake, whether through his site or as visitors. I spent a very happy time learning about Moore's matsutake under tanoak, Shasta red fir, and pine.

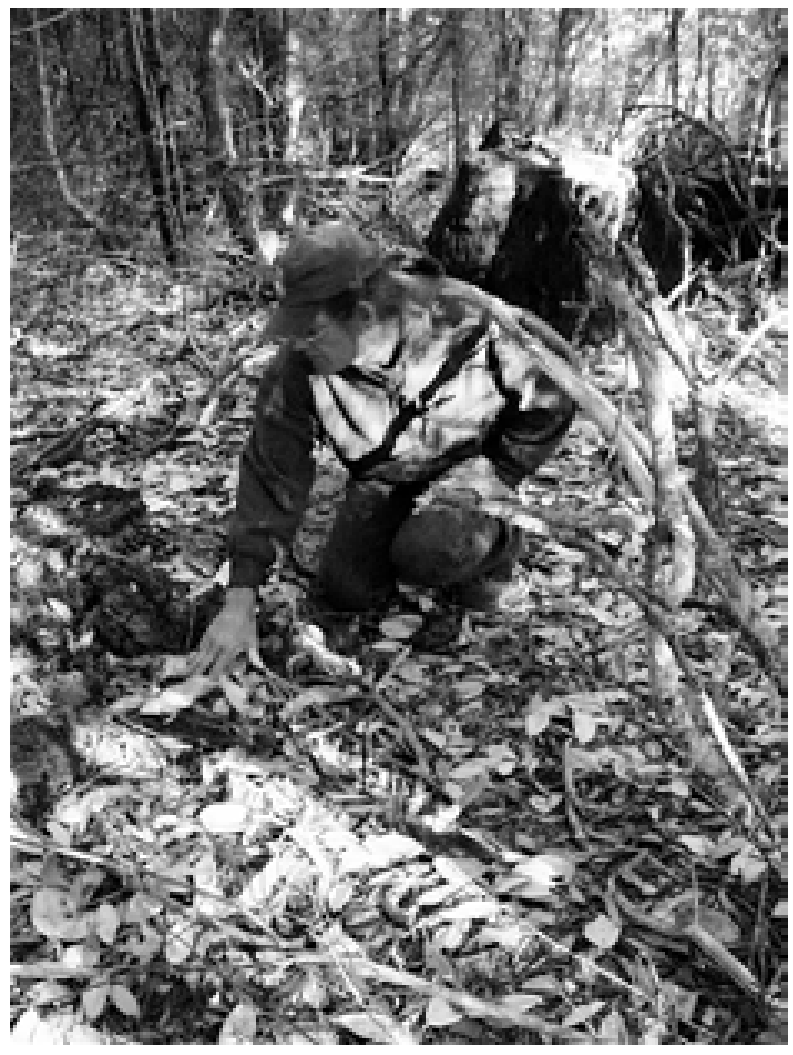

What if science were open to every 'matsiman'?

7 Ibid., 'Who is Matsiman?' 


\section{Conjuring matsutake worlds: toward more inclusive modes of wellbeing}

Consider a different mushroom-based project of inclusion: the appeal to matsutake to help us build modes of wellbeing in which humans and nonhumans alike might thrive. The charismatic and energetic organizer Fumihiko Yoshimura has been studying and working with matsutake for most of his life. As a scientist, Dr. Yoshimura conducts some of his work in laboratories and forest field sites. But he is also founder of the Matsutake Crusaders, a citizens' initiative based in Kyoto to revitalize Japan's matsutake forests. The Matsutake Crusaders are volunteers; their job is sculpting the forest to bring back the health of red pine with its associate, matsutake. Matsutake here is not just a delicious food; it is also a symbol, and a participant in a world of ecological wellbeing. The Crusaders' motto is 'Let's revitalize the forest so we can all eat sukiyaki'. Sukiyaki (a meat and vegetable stew always best with matsutake) is a popular and traditional food. Sometimes sukiyaki is eaten on festive occasions, and sometimes in outdoor outings in which urbanites enjoy the fresh air. Eating together in appreciation of the natural world, people revitalize themselves as well as their forests. Dr. Yoshimura's movement brings members into the countryside to offer new vitality to the world.

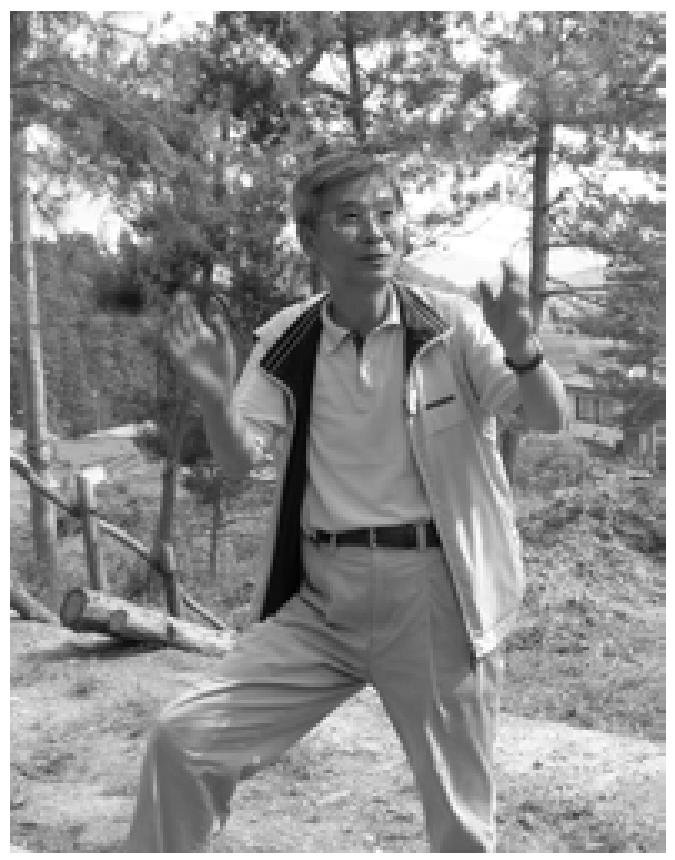

Dr. Yoshimura is able to draw on a long legacy of applied matsutake science. Attempts to nurture and promote matsutake are very old in Japan. ${ }^{8}$ In the

8 Dr. Yoshimura draws my attention to the first written record of matsutake in Japan, in an anthology of waka poems (Man-nyo Shu 10. 2233, 650-750 C.E.). The poem, 'The Aroma of Pine Mushrooms', was translated 
twentieth century matsutake became an object of modern science. Minoru Hamada deserves special credit for realizing that matsutake research could address basic biological questions and simultaneously promote the production of a valued economic product. Dr. Hamada trained a cohort of matsutake researchers after World War II who in turn trained many of today's researchers. Makoto Ogawa, one of Dr. Hamada's students, was particularly effective in spreading matsutake research; he convinced the government to send matsutake researchers to every prefectural forestry station. ${ }^{9}$ Dr. Yoshimura spent most of his career in Iwate prefecture conducting matsutake research and promoting matsutake.

Promoting matsutake does not require domestication. While researchers have successfully grown matsutake mycelia, and even matsutake-pine mycorrhiza, in laboratories, no one has yet succeeded in getting these cultivated stocks to produce a mushroom. Instead, the focus in promoting matsutake is in making the kind of forest in which matsutake likes to live. Matsutake in Japan associates with red pine, Pinus densiflora. Red pine is a pioneer species of disturbed areas. For many centuries, villagers in Japan have disturbed forests through shifting cultivation and selective harvesting of broadleaf trees. The wood of broadleaf trees is used for firewood and charcoal. Villagers also collected herbs and grass and raked leaves for green fertilizer. This left bright, open hillsides with exposed soils: the situation preferred by red pine.

All this changed after World War II. Villagers started to use fossil fuels for heating and tractors instead of oxen. No one bothered to collect firewood, to make charcoal, or to gather leaves and grass. Young people moved to the city, leaving villages to the elderly. Village forests were neglected. Broadleaf trees grew back with a vengeance, shading out pines. Meanwhile, the pines were weakened by a wilt disease spread by an imported nematode. In the deep shade of the neglected broadleaf forest, pines died. Without their hosts, matsutake expired. Many a matsutake lover described hillsides he had known as a boy white with mushrooms, now without a single pine.

By the 1970s, urbanites were missing the village forests of their youth - places where wildflowers in spring or fireflies in summer might be glimpsed, or autumn colours admired. ${ }^{10}$ Citizens' movements grew up to address the impoverished

by Minoru Hamada as follows: 'The path to the hilltop from Takamatsu, Tall Pine Tree Village, has just been barred by the rings and lines of rapidly rising caps (of pine mushrooms). They emit an attractive autumnal aroma that refreshes me a great deal...'.

9 See Tsing and Satsuka for citations and a fuller treatment of this history.

10 The distinction between two kinds of broadleaf trees - deciduous and evergreen - is important in Japan. Deciduous broadleaves are preferred for firewood and charcoal. Villagers selectively weeded out the evergreen broadleaves. Meanwhile, the deciduous broadleaves grew back from coppice shoots after harvesting, thus establishing their dominance in the forest architecture. This helped to keep forests bright and open. In the late twentieth century when no forest management was being done in many areas, evergreen broadleaves, no 
environment of modern Japan. Unlike wilderness advocates in the United States, many Japanese focused on the lively ecologies of sites of long-term human disturbance: the verges of roads, the flood plains of rivers, village irrigation networks and rice paddies - or the open village forest. In these disturbed sites, something that might be called a sustainable relationship between humans and nonhumans could be demonstrated in microcosm. Preservation would mean not human abandonment but rather guided disturbance. In the process of learning ancient methods of disturbance, modern citizens could educate themselves about being in nature.

Dr. Yoshimura's Matsutake Crusaders emerged from this milieu. The name draws on the popularity of a mobilization of the 1980s, the Woodland Maintenance Crusaders, in which student volunteers removed grass and weeds that were choking the forest. ${ }^{11}$ Dr. Yoshimura's group has the added excitement not just of fixing the forest, but also, possibly, of producing tasty mushrooms. His methods are to advantage pine: to remove evergreen broadleaves completely, thus opening the hillside to light. As pine comes back, the hillside becomes an open forest where spring wildflowers, rabbits and hawks can find niches. But no one can guarantee mushrooms. The volunteers must do the work for the love of nature.

All of this takes me to one Saturday in June 2006, when my research collaborator Shiho Satsuka and I joined the Crusaders for a day of forest work and play. The site was a steep hillside that had become choked with young evergreen broadleaves. The many thin trees were so close together that a person could not reach-less walk - through. It was dark and unappealing for humansand many nonhumans. The only way to handle the situation, Dr. Yoshimura explained, was to clear the land. Only red pine would be saved. When Dr. Satsuka and I arrived, a group of men were busy removing trees and shrubs. Surprisingly, to me, they were even digging out the roots of the broadleaves, removing them to a brush pile. It was labour-intensive work, all done with hand tools. It would take years to clear even this one mountain. Still, everyone there was cheerful and full of enthusiasm.

Dr. Yoshimura showed us the adjoining hillside, which, after much work, was open, bright, and green with pine. 'This is what this hillside might have looked like in earlier days', he explained. Already animals and birds had been sighted; they were hoping and waiting for mushrooms. Beside this hillside there were other group projects: a garden; a charcoal-making kiln; a beetle-breeding mound for hobbyists. And at the base of the hill there was food and tea and conversation. At lunchtime, the workers sweating on the hill came down. Their

longer cut back, became the dominant forest vegetation. Besides discouraging pine and its associates, these new dark forests do not allow the familiar wildflowers, birds and insects associated with earlier village forests. They also do not offer autumn colours.

11 See Nakagawa (114) for a discussion of these earlier Crusaders and their context. 
colleagues had been hard at work constructing a long bamboo aqueduct. It would be the extended serving plate for a special summer dish: noodles in the stream (or 'flowing somen'). We ran cool water down the aqueduct and poured in hot steaming noodles. Everyone gathered by the 'stream' and grabbed noodles with our chopsticks, mixing them with sauces in ready bowls. There was much joking and laughter. I met rural landowners and urban housewives and even an anthropology graduate student. Someone offered an amusing haiku about coming from America. Someone showed off the ingeniously handcrafted 'crabs' he had made. Someone showed pictures from his own property, which he hoped to revitalize using Crusader techniques. We lingered long before going back to work. This was a revitalisation not just for the hillside but also for all the senses.

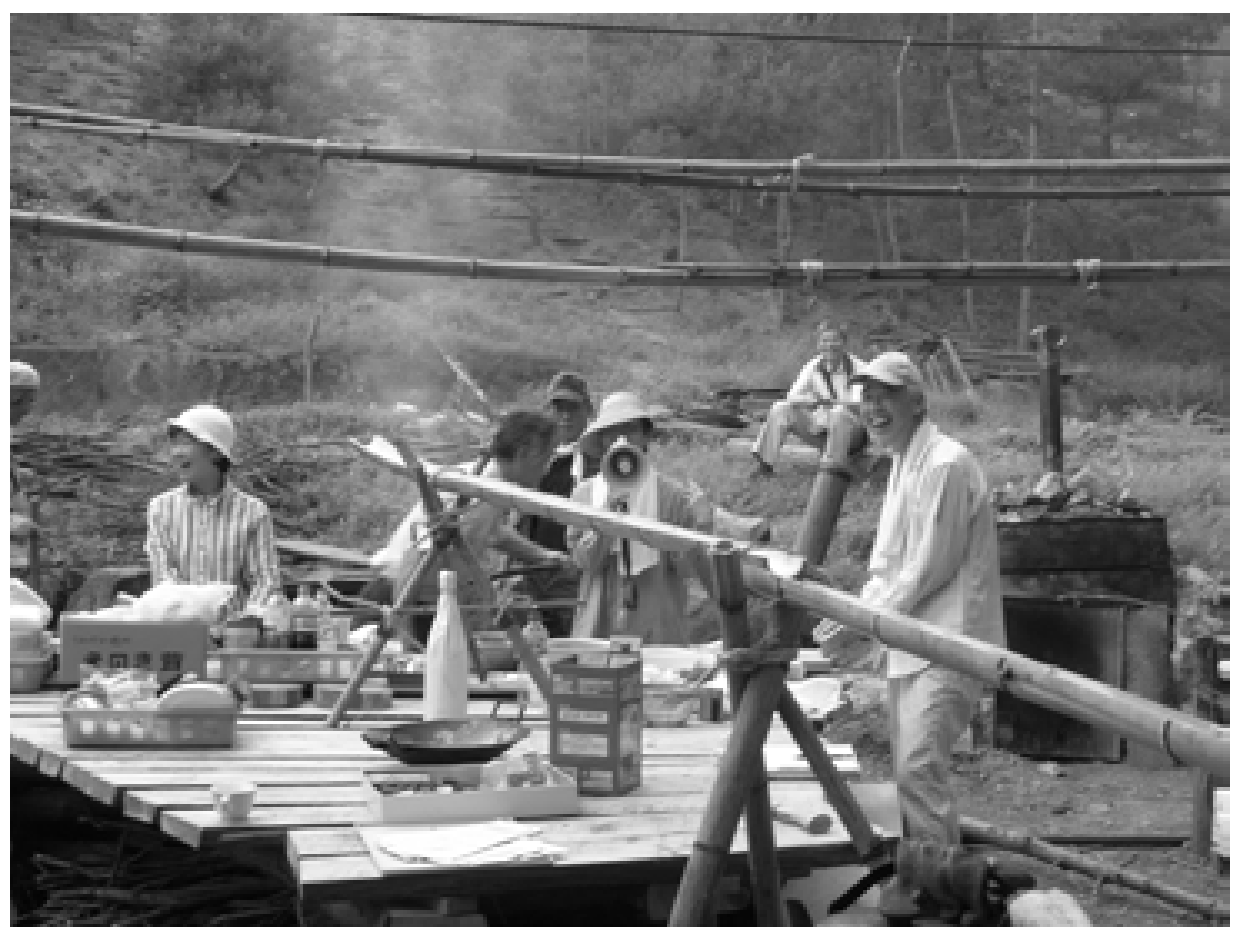

In fall 2008, the hillside produced its first matsutake mushrooms. The Crusaders were delighted.

\section{Loving in a time of extinction}

The forms of love I have called up in this chapter are diverse, even contradictory. Despite the fact that they both address their efforts to matsutake mushrooms, Andy Moore and Dr. Yoshimura might find each other's practices strange. The sciences, and the social and natural ecologies, in which they participate are linked, but not continuous in any simple sense. I have written elsewhere about 
the glancing relationship between 'forest ecologies' as observed and interpreted in Oregon and Kyoto (Tsing and Satsuka; Tsing). Here, the reason for including details about science and ecology in each region is only to show the sources of each creative intervention. For Andy Moore, the wild mushroom economy, in its open opportunity for eccentrics, also creates the possibilities of vernacular science, that is, knowledge production in which ordinary people can participate. For Dr. Yoshimura, citizens' interest in environmental remediation offers the chance to build connections between human and nonhuman wellbeing. For him, efforts to re-sculpt forest landscapes make the volunteers happier and healthier even as they make a more hospitable multispecies environment.

Each of these creative interventions contrasts sharply with the hegemonic, extinction-oriented creed one might call 'plantation science'. Plantation science teaches us to work for full control of our crops. Managers and experts, working together, should be able to manipulate relevant humans and nonhumans. For those who love wild mushrooms, such control is not an object; indeterminacy is part of the point. Wherever volunteers gather to promote disturbance forests, or pickers stop to ponder why the mushrooms come up, plantation science loses a little authority.

In plantation science, expertise and management work together; harvesters are never asked to comment on their crops. In plantation science, wellbeing is a formula calculated from above; collateral damage is expected, and no one stops to ask, 'Wellbeing for whom?' In plantation science, experts and objects are separated by the will to power; love does not flow between expert and object. In contrast, my stories tell how advocacy for mushrooms can lead to projects for democratic science and publicly inclusive wellbeing. It's the passion for the mushroom - in all the details of its social-natural ecology - that makes these projects possible.

There is a new science studies afoot, of which this special issue is a part, and its key characteristic is multispecies love. Unlike earlier forms of science studies, its raison d'être is not, mainly, the critique of science, although it can be critical. Instead, it allows something new: passionate immersion in the lives of the nonhumans being studied. Once such immersion was allowed only to natural scientists, and mainly on the condition that the love didn't show. The critical intervention of this new science studies is that it allows learnedness in natural science and all the tools of the arts to convey passionate connection. In common with nature writing, its job is communication and mobilizing the public. It also takes on the task of asking hard questions, philosophical, social, and scientific, and, with the privilege of scholarship, lingering over each. Writers of this new genre, including myself, are excited by the chance to trespass across the boundaries between the natural sciences and the humanities. But we are only successful with the genre to the extent that we can open new spaces in the 
public imagination, spaces not much travelled by either passion or attention. For that, we need to summon the unexpected talents others have brought to this task. My stories of mushroom lovers and their projects are a small contribution.

Anna Tsing is Professor of Anthropology at the University of California at Santa Cruz. She is the author of numerous books and articles, including the award winning Friction: An Ethnography of Global Connection (2005) and In the Realm of the Diamond Queen: Marginality in an out-of-the-way place (1993).

\section{Image Credits}

Figure 1: Jacob E. Lange, Flora agaricina danica, 1935-1940, Volume 1, Plate $7 \mathrm{~A}, \mathrm{C}$.

Figure 2: Minakata Kumagusu, Kinrui Zufu [Color Illustrations of Fungi], 2007, p.76. Image copyright National Science Museum, Japan.

Figure 3: Photograph by the author.

Figure 4: Photograph by the author.

Figure 5: Photograph by the author.

\section{Works Cited}

Arora, David. Mushrooms Demystified: A Comprehensive Guide to the Fleshy Fungi. Berkeley: Ten Speed Press, 1986.

Blacker, Carmen. 'Minakata Kumagusu, 1867-1941: a genius now recognized.' Collected Writings. New York: Routledge, 2000. 235-247.

Blyth, Reginald H. 'Mushrooms in Japanese verse.' Transactions of the Asiatic Society of Japan. Third series, 11 (1973): 93-106.

Fries, Elias. [1857] 'A short account of my mycological study.' Trans. Ib Magnussen and Annie Fausboll. Friesia 5.2 (1955): 135-160.

Hansen, Lise and Henning Knudsen, eds. Nordic Macromycetes. 3 vols. Copenhagen: Nordsvamp, 1992-2000.

Lange, Jacob E. Flora agaricina danica. Copenhagen: Society for the Advancement of Mycology in Denmark and the Danish Botanical Society, 1935-1940. 
Minakata Kumagusu. [1921] Minakata Kumagusu Kinrui Zufu [Colour Illustrations of Fungi]. Ed. Watariumu Bijiutsukan and Hiromitsu Hagiwara. Tokyo, Shinchosa: 2007.

Nakagawa, S. 'Nationwide partnerships for satoyama conservation.' Satoyama: The Traditional Rural Landscape of Japan. Ed. K. Takeuchi, R.D. Brown, I. Washitani, A. Tsunekawa and M. Yokohari. Tokyo: Springer, 2003. 111-119.

Tsing, Anna. 'Worlding the matsutake diaspora, or, Can actor-network theory experiment with holism?' Experiments in Holism. Ed. Nils Bubandt and Ton Otto. London: Wiley-Blackwell, 2010. 47-66.

-, and Shiho Satsuka. 'Diverging Understandings of Forest Management in Matsutake Science.' Economic Botany 62.3 (2008): 244-256. 